\title{
Egy rég elfeledett szegedi gyógyvízről
}

\author{
Gömör Béla dr.
}

\author{
Semmelweis Egyetem, III. Belgyógyászati Klinika, \\ Reumatológiai és Fizioterápiás Tanszéki Csoport I. sz. részlege a Budai Irgalmasrendi Kórház telephelyén
}

Ez az orvostörténeti dolgozat egy antikvitásnak számító, 105 éves kiadvány [1] alapján emlékezik meg az egyik szegedi keserüvizes gyógyforrásról, bemutatva az akkori orvosi és laikus vélekedéseket a gyógyvízről.

A 62 oldalas füzetet, a „Masa István Petőfi sós-keserü gyógyvizforrása Szegeden”-t maga a tulajdonos adta ki, a háború első évében, az akkor már 27 éve forgalomban lévő gyógyvízről. A füzet az általa írt, „A szegedi Pető $i$ gyógyforrás ismertetése” oldalaival kezdődik (1. ábra), melyben szívhez szólóan leírja, hogy „...a véletlen útján vezetett engem a gondviselés ezen hatalmas gyógyerő birtokába...”. Ugyanis teljesen hasonló eset fordult elő Harkány után Szegeden is. Mint közismert, 1823-ban egy Pogány János nevű gyűdi lakos teljes sikerrel áztatta beteg lábait a mocsárlecsapolás után szabadon folydogáló harkányi vízben. Szegeden egy szegény munkásember, akinek évek óta erôs, hasogató lábfájdalmai voltak, 20 napon át csodálatos eredményt elérve mosogatta lábait a Masa István birtokában lévő, egykori Berlini körút 9. szám alatti ház udvarán ásott kút vizével. Ezen véletlenül fölfedezett sikerén buzdult fel Masa István, és élete hátralévő részében lelkesen foglalkozott a gyógyvíz üzleti kiaknázásával. - Ezután következik a füzetben „A t. Közönséghez” mondhatni kiáltvány, végül jön a „Használati utasítás" 28 pontban.

Magyarország - kitüntetetten a Trianon előtti történelmi Nagy-Magyarország, de még a jelenlegi is - közismerten gazdag gyógyvizekben. Közöttük különleges helyet foglalnak el az igazi természeti kincset jelentő keserúvizek. Ezek a felszín közeli talajvizekből származnak, és nagy mennyiségben tartalmaznak szulfátokat. A szulfátionok okozzák keserú ízüket. Ha a vízben a magnézium-szulfát van túlsúlyban, akkor tiszta keserúvíz a nevük, ha a nátrium-szulfát az uralkodó elem, akkor glaubersós vízrôl beszélünk. Hígítva jól használhatók a gyomor-, bél-, máj-, epebetegek ivókúrájára, hashajtó hatásuk közismert.

Ezek az ásványvizek csak speciális geológiai körülmények hatására jöhetnek létre. Az egyedi geokémiai folyamatok ezen összjátéka világszerte ritkaságnak számít. Az 1948-ban még múködő kutatóintézet alapos közlést tett közzé e tárgyban [2]. Vezető helyen a budai telephelyek vannak, a Dobogó-völgyben föllelhető Saxlehner
Hunyadi János keserúvize, az őrmezői Ferencz József keserűvíz és Apenta keserúvíz, az Erzsébet királyné-keserûvízforrások a kelenföldi síkon, a budai Mária-források és a budaörsi Herkules keserúvíz, de a Komárom megyei Igmándi keserúvíz is kellő hírnevet vívott ki magának.

Visszatérve Szegedre, a város határában több helyen is volt keserüvíz, köztük a Petőfi-forrás. A szakforrásnak nem nevezhető várostörténeti könyv is megemlékezik róla: „Legutóbb a berlini körúton, a szegények háza mellett ásott s „Petöfi”-röl nevezett kút keserü vize keltett feltünést, mely a budai gyógyvizekkel vetélkedik” [3]. Értelemszerüen az ország vizeit listázó szakkataszter is fölsorolja a Petőfi-gyógyforrást [4]. Több mint fél évszázaddal később az alapos és hatalmas kötet is említi ezt a gyógyvizet [5]. Eredetileg ez telek, és így a gyógyforrás lelőhelyének címe Berlini körút 9. volt, ahogy a Masa-féle kiadvány is írja, a Szegény-ápolda mellett. Azonban a 2. világháború befejeztével a körútrész neve nem maradhatott meg a volt náci állam fơvárosának nevén. A felszabadítási hála jegyében a körútszakaszt el is keresztelték Moszkvai körútnak, s ennek megfelelően manapság, az egykori gyógyforrásépület helyén lévő egyetemi épület címe Moszkvai körút 9.

A kút 12,8 méter mély, a víz hőfoka $13,6^{\circ} \mathrm{C}$, a vízoszlop magassága 5-5,5 méter. Víztiszta, szagtalan keserüvíz.

A Lengyel Béla vegyész, egyetemi tanár által az 1886. év augusztusában végrehajtott vegyelemzés szerint a víz összetétele a következő (az eredeti meghatározások nómenklatúráját használva):

$\begin{array}{ll}\text { Chlornatrium } & 104.9964 \\ \text { Kénsavas magnesium } & 82.2074 \\ \text { Clormagnesium } & 33.1863 \\ \text { Légenysavas natrium } & 14.3872 \\ \text { Kénsavas calcium } & 23.6281 \\ \text { Szénsavas calcium } & 7,8792\end{array}$

további elenyésző részek összességében

267.9038 szilárd alkatrész.

A gyógyvíz forgalomba adása Masa István által - a megfelelő engedélyek beszerzése után - 1887. szeptember 18-án történt meg. 
A nagy millenniumi seregszemlén - „a nyolczvankét fürdó és gyógyforrás kiállitásában” - Masa István gyógyvízforrás-tulajdonos mint egyetlen szegedi állított ki [6].

A tulajdonos egyébként 1843 és 1921 között élt. Elhalálozása és az ország helyzetének jelentős megváltozása nyomán a virágzó gyógyforrásüzem hanyatlani kezdett. A helyi újság 1926-ban tette hírré, hogy az örökösök már el is akarnák adni a gyógyforrást és a palackozót [7]. Masa két lánya és rokkant veje nem értett az üzleti részhez. Pedig: „A háború elött 40 lány fejtett vizet az üvegekbe. Naponta 2-3 vagon indult külföldre.” De aztán jött Trianon, és a vámsorompók megpecsételték a Petőfi-forrás sorsát. A hatvanas évekből származó korrekt helyi újságcikk összefoglalja a gyógyforrás történetét [8].

Ismereteink szerint a gyógyvíztermelést 1950-ben szüntették meg. Egy évtizeddel később, egy Szegeden tartott orvoskongresszus alkalmával a látogatók javasolták a kitisztítást, újraüzemeltetést és az elavult berendezés fölújítását. Noha a városi egészségügyi vezetés tudott a helyzetről, intézkedés már soha nem történt.

Az igazi orvostörténeti érdekesség, az, hogy bár a meglelt keserúvíz analógiáit jól ismerték Budáról, a Használati utasítás - mai szemmel nézve minden alapot nélkülözve - kiterjedten ajánlja mindenféle, nem az emésztőrendszerre való hatás miatti bajra is. Így „köszvény ellen”, „túlságos elhizás ellen”, „a szív elzsírosodása ellen”, „zívszoritás ellen”, „belsö daganatok és egyéb fájdalmak ellen”, „hideglelés ellen”, valamint „szem elgyengülése és a látás lassankinti elvesztése ellen” és még sok minden más esetben. Hiszen az teljesen rendben valónak tünik, hogy: „ha hasmenése vagy rendetlen székürülése van az embernek, meghajtja és rendes székürülést csinál” ezért az utasítás: a betegnek meg kell inni három deci Petőfi gyógyvizet. Az összegző megállapítás: „csodás sikerrel kigyógyultak mindnyájan, akik ezen vizet használták eddig” - igen hasonlít a manapság elviselhetetlenné burjánzott egészségügyi médiahirdetések hangvételére.

A „Függelék” „orvosi birálatok”-at tartalmaz. Igaz, a kor ezen megnyilatkozásait például a Lukács-fürdőről írt német nyelvü csinos kötetből is ismerhetjük [9]. A régi vacak kis fürdő az 1893-94-es építkezés során luxusszálló foglalatába került. A többmondatos, egyértelműen pozitív véleményeket Korányi Frigyes, Kétly Károly, Purjesz Zsigmond neves belgyógyászok, illetve Herczel Manó és Réczey Imre sebészek, valamint Laufenauer Károly ideggyógyász egyetemi tanárok, továbbá Stiller Bertalan, a Zsidókórház igazgatója és Petz Lajos Győrből fogalmazták meg.

A Petőfi keserúvízről 15 véleményt olvashatunk a referálás alatt lévő füzetből. Mindegyiket névvel, pontos titulussal és a múködés helyének megadásával illették. Igen érdekes, hogy a többség - pontosan tucatnyi ajánlás - Bécsből származik. Köztük olyan hírességtől, mint Rudolf Chrobak, akiről nőgyógyászati mütéti eljárást is elneveztek. Lakonikusan és korrekten fogalmaz: „A Pető $i$ keserüvíz a klinikai betegeknél való használatkor mint enybe és könnyü hashajtószer bizonyult be.” Nyilvánvaló,
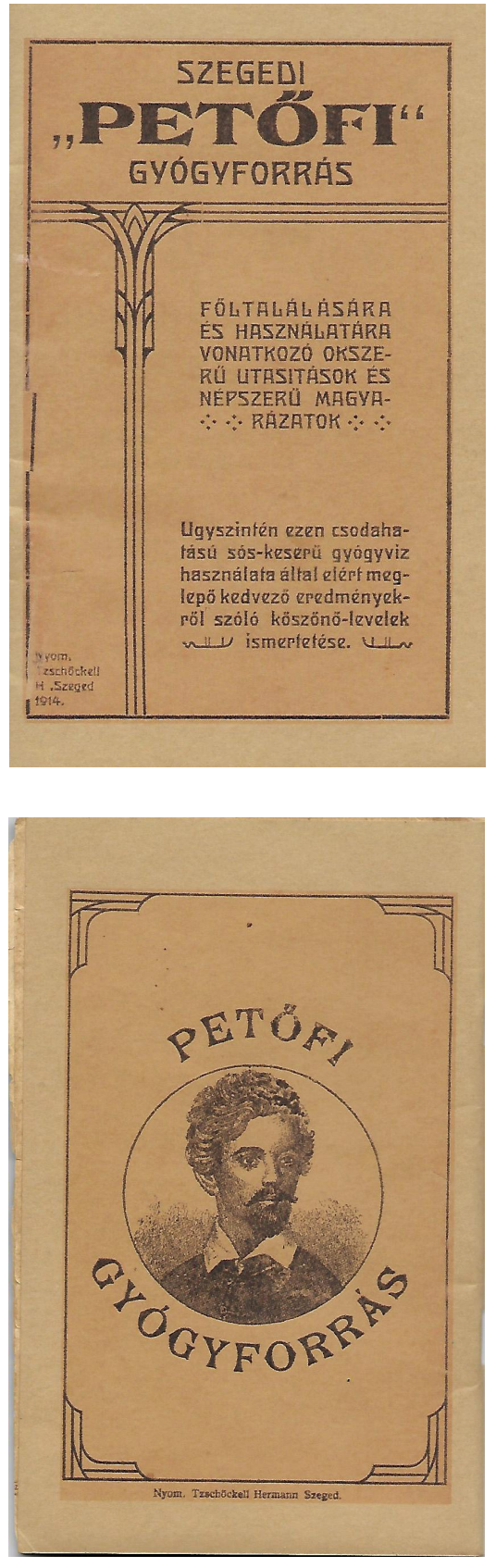

1. ábra és hátsó borítója

hogy a tulajdonos nem sokkal a megnyitás után mindenhová eljuttatta a gyógyvizet, ma azt mondanánk, mintát küldött. Írják is „Szíves küldeményét megköszönve...”, „Fogadja küldeményéért forró köszönetemet...”. Az orvosi vélemények - a Használati utasítás szerinti mindenféle indikációk ellenére - kizárólag az emésztőszervi hatásokról szólnak, az egy kivételtől eltekintve, amikor Frey Lajos ezt tanúsítja Bécsből: „Gazdag alkálikus tartalmánál fogva e viz kitüno" hatással bir a lélegzési szervek katarrhusos bántalmainál...”- ami kórtanilag teljesen meg is felel a valóságnak.

Nem így a laikus vélemények! Amiket a kiadvány leghosszabb részén, 25 oldalon elterülő, a szegedi Petőfi 
sós-keserú gyógyvíz által kigyógyultak KÖSZÖNETNYILVÁNÍTÁSAI mutatnak be. Illusztrációként, a részleteket mellőzve, csupán néhány cím a csodahatásokról: „Hálaköszönet nyilvánitás aranyér-, májdaganat-és vérhasról”. „8 éves fekélyseb, a két lábról lerothadt a hus és darabokban hullott ki és a csontok kezdtek kilátszani.” "6 éves lábfölzsugorodásból kigyógyult köszönete.” „Idegbajból és rángatódzásból kigyógyult hálanyilatkozata.” „Szemfájás, vértisztátlanság és lábtörésben szenvedō köszönete.” „5 évig méhbajban szenvedö nő hála-köszönő levele.” „Süketségből kigyógyult hálaköszönete.” Az utóbbiban a 60 éves Koszó Rozália írja Horgosról, hogy másfél évig volt süket. A kiskönyv utasítása alapján kezdte használni a vizet, és 8 nap múlva egyik füle felpattant, és hallása megjött. Sokkal hosszabban és szívhez szólóan ecsetelte egy 37 éves szülésznő, hogy miután szélütés miatt a bal oldala lebénult: „Az Ön gyógyvizét kezdtem inni és meleg vizzel a szél által ért testrészemet napjában háromszor erôsen megdörzsöltem, azután azon vizbe rubát mártottam séjjelve a beteg testrészt becsavartattam. Hat hétre az ágyból már föl birtam kelni és öt hónapra teljesen fölgyógyultam, amit az Ön Petöfi gyógyvizének köszönhetek.” Bátorkodom kijelenteni, hogy a súlyos bajokba esett embertársaink vágyai és vélekedése - a modern medicina szédületes előrehaladása ellenére - a mai napokra nem sokat változtak. Vágynak a csodákra, az egyes esetek gyógyulását soha nem az idő múlásának, más tényezőknek, hanem az alkalmazott szernek tulajdonítják - és ami a legnagyobb baj, más laikusok ebból példát merítenek.

Az utolsó oldalon, a „Megrendelések” részben található az „Utmutató az idegeneknek”. Bájos praktikus tanácsok a vasúttal, gőzhajóval érkezóknek, hogy hogyan tudják a legkönnyebben felkeresni a Berlini nagykörúton lévő gyógyforrást.

\section{Irodalom}

[1] "PETÓFI" medicinal spring in Szeged. [Szegedi „PETÖFI" gyógyforrás.] Nyomtatta: Tzschöckell Hermann, Szeged, 1914. [Hungarian)

[2] Vendl A. The hydrogeology of bitter water places of Budapest. [A budapesti keserúvizes telepek hidrogeológiája.] A Budapesti Központi Gyógy- és Üdülőhelyi Bizottság Rheuma- és Fürdőkutató Intézet kiadványa, Budapest, 1948. [Hungarian)

[3] Reizner J. History of Szeged I-IV. [Szeged története I-IV.] Szegedi Szabad Királyi Város Közönsége, Szeged, 1900. [Hungarian)

[4] Papp S, Hankó V. (eds.) The mineral waters and health resorts of the sometime Hungarian empire. [A magyar birodalom ásványvizei és fürdőhelyei.] Magyar Balneologiai Egyesület kiadványa, Budapest, 1907. [Hungarian)

[5] Schulhof Ö. (ed.) The mineral waters of Hungary. [Magyarország ásvány- és gyógyvizei.] Akadémiai Kiadó, Budapest, 1957. [Hungarian]

[6] „Szegedi Napló”, 1896. május 28. [Hungarian]

[7] Szeged's Petőfi-forrás to be put up for sale. [El akarják adni a szegedi Petőfi-forrást.] Dél-Magyarország, 1926. július 11. 2. [Hungarian]

[8] Oltvai F. Tracing the story of an ancient medicinal spring at Szeged. [Egy régi szegedi gyógyforrás nyomában.] Dél-Magyarország, 1964. szeptember 29. [Hungarian]

[9] Bosányi B. Saint Lucas bath in Óbuda. Pátria, Budapest, 1905. [in German]

(Gömör Béla dr., Budapest, Árpád fejedelem útja 7., 1023 e-mail: gomorbela@gmrbt.hu)

\author{
"Post festam (festa)." \\ [Ünnep(ek) után. - Elkésve.)]
}

